\title{
A ACESSIBILIDADE EM CIDADES HISTÓRICAS PARA AS PESSOAS COM DEFICIÊNCIAS: DESAFIOS NO CUMPRIMENTO DAS LEGISLAÇÕES VIGENTES
}

\author{
ACCESSIBILITY IN HISTORICAL CITIES FOR PERSONS WITH DISABILITIES: \\ CHALLENGES IN COMPLYING WITH THE CURRENT LAWS
}

\author{
ACCESIBILIDAD EN CIUDADES HISTÓRICAS PARA PERSONAS CON \\ DISCAPACIDAD: DESAFÍOS EN EL CUMPLIMIENTO DE LA LEGISLACIÓN \\ ACTUAL
}

\begin{abstract}
LÚCIA MARIA MORAES https://orcid.org/0000-0002-9459-3948 / http://lattes.cnpq.br/2460294440897616 / lucia.dhescmoradia@gmail.com Pontifícia Universidade Católica de Goiás - PUC-GO.

Goiás, GO, Brasil.
\end{abstract}

\author{
DANIELLY APARECIDA DE SOUZA CARVALHO SANTANA \\ https://orcid.org/0000-0001-6242-3373 / http:/ / lattes.cnpq.br/9684157011964704 / dascarvalho@hotmail.com \\ Pontifícia Universidade Católica de Goiás - PUC-GO. \\ Goiás, GO, Brasil.
}

\section{RESUMO}

O atendimento às legislações referentes à preservação de patrimônio histórico e à acessibilidade é um desafio. Porém, não pode ser um entrave para o acesso dessas pessoas, privadas, por muitos anos, de tantos direitos. Esta pesquisa objetiva apresentar a importância da acessibilidade também nas cidades históricas para pessoas com deficiência. A metodologia utilizada é a pesquisa bibliográfica e a análise das legislações federais que normatizam o tema. Os resultados revelaram que, não obstante o Brasil tenha uma legislação vasta quanto à acessibilidade e ao patrimônio histórico - considerado rígido, sendo previstas penalidades em caso de infrações -, há desafios no cumprimento das normas. A dificuldade de acessibilidade da pessoa com deficiência é uma herança com consequências presentes. 0 cenário urbano é crítico em cidades históricas. Conclui-se que, é necessário se construir uma melhor consciência social, e, consequentemente, permitir o digno acesso dessas pessoas a esses espaços.

Palavras-chave: Acessibilidade; Cidades Históricas; Patrimônio Histórico; Pessoa com Deficiência.

\begin{abstract}
Comply with legislation regarding the preservation of historical heritage and accessibility is a challenge. However, it cannot be an obstacle to the access of these people, historically deprived of so many rights. This research aims to present the importance of accessibility also in historical cities for persons with disabilities. The methodology is bibliographic research and analysis of federal laws that regulate the theme. The results show that, despite Brazil having vast legislation regarding accessibility and historical heritage - considered rigid, with penalties foreseen in case of infractions -, there are challenges in complying with the rules. It is concluded that the difficulty of accessibility for persons with disabilities is an inheritance with present consequences. The scenario is critical in historic cities. It is concluded that, it is necessary to build a better social conscience, and, consequently, allow the dignified access of these people to these spaces.
\end{abstract}

Keywords: Accessibility; Historical Cities; Historical Heritage; Persons with Disabilities.

\section{RESUMEN}

El cumplimiento de la legislación sobre la preservación del patrimonio histórico y la accesibilidad es un desafío. Sin embargo, no puede ser un obstáculo para el acceso de estas personas, privadas, durante muchos años, de tantos 
derechos. Esta investigación tiene como objetivo presentar la importancia de la accesibilidad también en ciudades históricas para personas con discapacidad. La metodología utilizada es la investigación bibliográfica y el análisis de las leyes federales que regulan el tema. Los resultados revelaron que, a pesar de que Brasil tiene una amplia legislación sobre accesibilidad y patrimonio histórico, considerado rígido, con sanciones previstas en caso de infracciones, existen desafíos para cumplir con las normas. La dificultad de accesibilidad para personas con discapacidad es una herencia con consecuencias actuales. El entorno urbano es crítico en las ciudades históricas. Se concluye que es necesario construir una mejor conciencia social y, en consecuencia, permitir el acceso digno de estas personas a estos espacios.

Palabras clave: Accesibilidad; Ciudades históricas; Patrimonio histórico; Persona discapacitada.

\section{SUMÁRIO}

INTRODUÇÃO; 1 DA PESSOA COM DEFICIÊNCIA: DO HISTÓRICO DE INVISIBILIDADE ÀS LEGISLAÇÕES PROTETIVAS; 2 DO DIREITO À ACESSIBILIDADE NA PERSPECTIVA DA PESSOA COM DEFICIÊNCIA; 3 DA PRESERVAÇÃO DO PATRIMÔNIO CULTURAL BRASILEIRO; 4 DAS CIDADES HISTÓRICAS: DA PROTEÇÃO À ACESSIBILIDADE; CONCLUSÃO; REFERÊNCIAS.

\section{INTRODUÇÃO}

A acessibilidade nas cidades e nos edifícios históricos é um desafio para a sociedade e para os órgãos responsáveis pelo cumprimento das legislações vigentes. As dificuldades são ainda maiores quando o acesso envolve a pessoa com deficiência.

Vale ressaltar que a Convenção Internacional dos Direitos da Pessoa com Deficiência, cujo texto foi aprovado pela Assembleia Geral das Nações Unidas em 13 de dezembro de 2006, ratificada pelo Brasil no ano de 2008, dando-lhe status de emenda constitucional, estabeleceu que o termo adequado a ser usado é pessoa com deficiência, para aquela que possui “impedimento de longo prazo de natureza física, mental, intelectual ou sensorial, o qual, em interação com uma ou mais barreiras, pode obstruir sua participação plena e efetiva na sociedade em igualdade de condições com as demais pessoas" ${ }^{1}$, desconsiderando qualquer outra terminologia anteriormente usada. Autores ou legislações citadas ao longo do texto com a utilização de nomenclatura divergente, dá-se em razão da que estava em vigor quando da publicação.

\footnotetext{
1 BRASIL. Decreto Legislativo $n^{\circ}$. 186, de 2008. Aprova o texto da Convenção sobre os Direitos das Pessoas com Deficiência e de seu Protocolo Facultativo, assinados em Nova lorque, em 30 de março de 2007. Disponível em: http://www.planalto.gov.br/ccivil_03/CONGRESSO/DLG/DLG-186-2008.htm. Acesso em: 23 abr. 2020.
} 
Foi da convenção que a Lei Brasileira de Inclusão (LBI, Lei 13.146/2015) extraiu a definição supracitada de pessoa com deficiência para os fins legais, em seu artigo $2^{\circ 2}$, tendo uma abrangência maior e com critérios mais flexíveis para a sua caracterização.

Objetiva-se apresentar a importância da acessibilidade nas cidades históricas para pessoas com deficiência. Como é possível assegurar a acessibilidade da pessoa com deficiência em cidades históricas com as legislações vigentes? Essa é a pergunta que norteia a pesquisa.

Se por um lado tem-se, juridicamente, a evolução e a extensão do conceito de acessibilidade, por outro, percebe-se um ordenamento jurídico rígido quanto ao patrimônio histórico - o que garante o usufruto das gerações futuras - e atitudes ou comportamentos que impedem ou que prejudicam a participação social dessas pessoas em igualdade de condições e oportunidades com as demais.

A metodologia adotada é a pesquisa bibliográfica sobre o assunto em estudo e a análise das legislações federais que normatizam o tema. Considerada tal abordagem, o presente estudo é considerado de natureza qualitativa.

Para uma melhor compreensão, este artigo está dividido em quatro capítulos, quais sejam: da pessoa com deficiência: do histórico de invisibilidade às legislações protetivas; do direito à acessibilidade na perspectiva da pessoa com deficiência; da preservação do patrimônio cultural brasileiro; e das cidades históricas: da proteção à acessibilidade.

\section{DA PESSOA COM DEFICIÊNCIA: DO HISTÓRICO DE INVISIBILIDADE ÀS LEGISLAÇÕES PROTETIVAS}

A deficiência foi vista por muito tempo como uma fatalidade. Associavam as deformidades à impureza e ao pecado. Sendo o homem criado à imagem e à semelhança de Deus, o que fosse contrário ao conceito de perfeição não era divino. Isso motivou o extermínio de muitas pessoas com deficiência em alguns países. Prática ainda comum, por exemplo, em determinadas tribos indígenas, inclusive, no Brasil. Como a Constituição Federal de 1988 reconhece "aos índios sua organização social, costumes, línguas, crenças e tradições, e os

\footnotetext{
2 BRASIL. Lei $n^{\circ} 13.146$, de 06 de julho de 2015. Institui a Lei Brasileira de Inclusão da Pessoa com Deficiência (Estatuto da Pessoa com Deficiência). In: Diário Oficial da União: seção 1, Brasília, DF, ano CLII $\mathrm{n}^{\circ}$ 127, p. 2-11, 07 jul. 2015. Disponível em: http://www.planalto.gov.br/ccivil_03/_ato20152018/2015/lei/l13146.htm. Acesso em: 23 abr. 2020.
} 
direitos originários sobre as terras que tradicionalmente ocupam" (art. 231, CF) ${ }^{3}$, a deficiência congênita e a gestação gemelar justificam a morte de muitos recém-nascidos.

Uma vida à margem da sociedade e sem garantia de direitos. Explicita Aranha que "A deficiência foi atribuída ora a desígnios, ora à possessão pelo demônio". 0 autor realça que "Por uma razão ou por outra, a atitude principal da sociedade com relação ao deficiente era de intolerância e punição, representada por ações de aprisionamento, tortura, açoites e outros castigos severos" ${ }^{4}$, sendo a pessoa tratada com desprezo e, muitas vezes, vivendo confinada em sua própria casa.

Elucida Corrêa, em estudo destinado à Educação Especial, que "a história da Educação Especial ou das pessoas com necessidades especiais, da Antiguidade até a Idade Média” era desumana. Realça que "o extermínio, a discriminação e o preconceito marcaram profundamente a vida dessas pessoas" ${ }^{5}$. Estes, quando sobreviviam, passavam a viver à margem da sociedade, exclusos do meio social, mesmo o familiar.

A dignidade humana, como atualmente compreendida, se assenta sobre o pressuposto de que cada ser humano possui um valor intrínseco. Na reconstrução de um mundo moralmente devastado pelo totalitarismo e pelo genocídio, a dignidade humana foi incorporada ao discurso político dos vitoriosos como uma das bases para uma era longamente aguardada de paz, democracia e proteção dos direitos humanos, como nos mostra os estudos de Barroso ${ }^{6}$.

Em consonância com o autor, Frias recorda que o "apelo à dignidade humana é comum não apenas no discurso jurídico, mas também na linguagem cotidiana"7 da população. Afirmações como "devemos garantir que todos tenham uma vida digna”, "todas as pessoas têm a mesma dignidade e os mesmos direitos", "ninguém deve sofrer tratamento desumano" são corriqueiras.

3 BRASIL. Constituição Federal. Brasília: Senado Federal, 1988. Disponível em: http://www.planalto.gov.br/ccivil_03/constituicao/constituicao.htm. Acesso em: 23 abr. 2020.

${ }^{4}$ ARANHA, Maria Salete Fábio. Integração social do deficiente: análise conceitual e metodológica. Temas psicol., Ribeirão Preto, v. 3, n. 2, p. 63-70, ago. 1995. Disponível em: http://pepsic.bvsalud.org/scielo.php?script=sci_arttext\&pid=S1413-389X1995000200008\&lng=pt\&nrm=iso. Acesso em: 23 abr. 2020.

${ }^{5}$ CORRÊA, Maria Ângela Monteiro. Educação Especial. v. 1 - $5^{\text {a }}$. reimp. Rio de Janeiro: Fundação CECIERJ, 2010. 211p. Disponível em: https://docplayer.com.br/85708679-Educacao-especial-volume-1-modulos-1-a4-maria-angela-monteiro-correa-apoio.html. Acesso em: 23 abr. 2020.

${ }^{6}$ BARROSO, Luís Roberto. A Dignidade da Pessoa Humana no Direito Constitucional Contemporâneo: Natureza Jurídica, Conteúdos Mínimos e Critérios de Aplicação. Versão provisória para debate público. Mimeografado, Dezembro de 2010. Disponível em: https://www.luisrobertobarroso.com.br/wpcontent/uploads/2010/12/Dignidade_texto-base_11dez2010.pdf. Acesso em: 23 abr. 2020.

${ }^{7}$ FRIAS, Lincoln; LOPES, Nairo. Considerações sobre o conceito de dignidade humana. Rev. direito GV, São Paulo, v. 11, n. 2, p. 649-670, Dec. 2015. DOI: https://doi.org/10.1590/1808-2432201528. Disponível em: http://www.scielo.br/pdf/rdgv/v11n2/1808-2432-rdgv-11-2-0649.pdf. Acesso em: 23 abr. 2020. 
A discriminação era também presente, quiçá mascarada nos dias atuais, no uso de termos pejorativos, como loucos, mongóis, mongoloides, dentre outros, para se fazer alusão à pessoa com deficiência. Reflexos esses de invisibilidade, constatados no aspecto social, indicam possíveis razões de uma tardia tutela jurisdicional.

Só após o fim da Segunda Guerra Mundial veio à baila a necessidade de se refletir e de se criar mecanismos capazes de garantir os direitos fundamentais. Em decorrência disso, importantes instrumentos jurídicos, como a Declaração Universal dos Direitos Humanos (1948), a Declaração Americana dos Direitos e Deveres do Homem (Bogotá, 1948) e a Convenção Americana dos Direitos do Homem (São José da Costa Rica, 1969), nortearam no início desse processo.

A preocupação de organismos internacionais em relação ao tema não é desarrazoada. Independentemente da época ou da sociedade em que se viva, em algumas mais e em outras menos, a discriminação em face de pessoas e/ou de grupos vulneráveis foi e é tão recorrente que se torna imprescindível a publicação e a aplicação de documentos legais relacionados e minimizar as violações de direitos.

Encorajadores dos direitos humanos, os tratados internacionais têm papel essencial no pós-guerra. Nesse sentido, escreveu Piovesan:

Em face do regime de terror, no qual imperava a lógica da destruição e no qual as pessoas eram consideradas descartáveis, ou seja, em face do flagelo da Segunda Guerra Mundial, emerge a necessidade de reconstrução do valor dos direitos humanos, como paradigma e referencial ético a orientar a ordem internacional. ${ }^{8}$

Nessa direção, cita Aranha que, durante a Segunda Grande Guerra Mundial, “fortaleceuse a convicção de que as pessoas deficientes podiam trabalhar, trabalhariam e que queriam uma oportunidade de ter voz ativa na sociedade" ", convicção muito estimulada na atualidade.

A Declaração Universal dos Direitos Humanos, proclamada pela Assembleia Geral das Noções Unidas, em 10 de dezembro de 1948, na França, em Paris, ressalta já no seu preâmbulo:

\footnotetext{
8 PIOVESAN, Flávia. A Constituição Brasileira de 1988 e os Tratados Internacionais de Proteção aos Direitos Humanos. EOS. Revista Jurídica da Faculdade de Direito. v. 2. n I. Ano II. Curitiba: Dom Bosco, 2008. Disponível em: http://www.observatoriodegenero.gov.br/menu/publicacoes/outros-artigos-epublicacoes/a-constituicao-brasileira-de-1988-e-os-tratados-internacionais-de-protecao-aos-direitoshumanos/at_download/file. Acesso em: 23 abr. 2020.

${ }^{9}$ ARANHA, Maria Salete Fábio. Integração social do deficiente: análise conceitual e metodológica. Temas

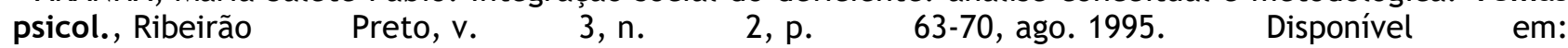
http://pepsic.bvsalud.org/scielo.php?script=sci_arttext\&pid=S1413-389X1995000200008\&lng=pt\&nrm=iso. Acesso em: 23 abr. 2020.
} 
Como o ideal comum a ser atingido por todos os povos e todas as nações, com o objetivo de que cada indivíduo e cada órgão da sociedade, tendo sempre em mente esta Declaração, se esforce, através do ensino e da educação, por promover o respeito a esses direitos e liberdades, e, pela adoção de medidas progressivas de caráter nacional e internacional, por assegurar o seu reconhecimento e a sua observância universais e efetivos, tanto entre os povos dos próprios Estados-Membros, quanto entre os povos dos territórios sob sua jurisdição. ${ }^{10}$

Assim, verifica-se que os instrumentos legais citados não são remotos e, mais recente, é a inquietação em garantir direitos em todas as áreas, os lugares e os espaços possíveis, o que tem resultado na publicação de novas leis, reflexões sobre terminologias usadas e criações de entidades, associações, conselhos que busquem e lutem pela inclusão social.

Associados ou não, elementos como: estarem em um cenário de desigualdade e de violência por anos; residirem em regiões mais precárias - nas conclusões dos Censos 2000 e 2010 constatou-se que a maior taxa de prevalência de pessoas com deficiência está na Região Nordeste do país -, fato que pode ser atribuído a uma distribuição de renda irregular e uma ineficiente aplicação dos tributos arrecadados na forma de políticas públicas; e, por ignorarem direitos já assegurados, colaboram para a invisibilidade da pessoa com deficiência. Requisitos estes que podem ter contribuído para que muitos fossem colocados à margem da sociedade.

De acordo com os dados extraídos de relatórios internacionais "estima-se que mais de um bilhão de pessoas vivam com alguma forma de deficiência, algo próximo de $15 \%$ da população mundial (baseado em estimativas da população mundial de 2010). Isso é mais alto do que as estimativas precedentes da Organização Mundial da Saúde $(\mathrm{OMS})^{11}$, as quais datam de 1970 e sugerem aproximadamente 10\%".

O texto da Convenção Internacional sobre os Direitos da Pessoa com Deficiência, como dito, foi aprovado pela Assembleia Geral das Nações Unidas em 13 de dezembro de 2006. Instrumento relevante nessa luta, com a sua assinatura, os países envolvidos são obrigados a promover, a proteger e a assegurar o exercício pleno dos direitos dessas pessoas e garantir que gozem de plena igualdade perante a lei.

10 ONU. Organização das Nações Unidas. Declaração Universal dos Direitos Humanos. Adotada e proclamada pela Resolução 217 A (III) da Assembleia Geral das Nações Unidas, em 10 de dezembro de 1948. Brasília. 1998. Disponível em: https://nacoesunidas.org/wp-content/uploads/2018/10/DUDH.pdf. Acesso em: 23 abr. 2020.

11 OMS. Organização Mundial de Saúde. Relatório Mundial sobre a Deficiência. Publicado pela Organização Mundial da Saúde em 2011 sob o título World Report on Disability. Disponível em: https://apps.who.int/iris/bitstream/handle/10665/44575/9788564047020_por.pdf;jsessionid=F4BC0CC3E2 F5E37A166B7F384E90D135?sequence $=4$. Acesso em: 23 abr. 2020. 
O Brasil tornou-se signatário e o texto é aprovado por meio do Decreto Legislativo 186/2008 ${ }^{12}$, dando-lhe status de Emenda Constitucional, promulgada pelo Decreto 6.949/2009.

Segundo o CENSO $2010^{13}$, realizado pelo Instituto Brasileiro de Geografia e Estatística (IBGE), da população residente no país, $23,9 \%$ possui pelo menos uma das deficiências investigadas: visual, auditiva, motora e mental ou intelectual, ou seja, próximo de 45 milhões de brasileiros. Em que pesem sejam indispensáveis os constantes progressos, é pacífico o entendimento de que alguns passos já foram dados para atender essa parcela considerável da sociedade.

Nesse toar, a assinatura da convenção desencadeou o interesse pela temática, e, em um contínuo processo de avanços legais, publica-se, no ano de 2015, a Lei Brasileira de Inclusão da Pessoa com Deficiência - LBI (Estatuto da Pessoa com Deficiência - Lei 13.146/2015), “destinada a assegurar e a promover, em condições de igualdade, o exercício dos direitos e das liberdades fundamentais por pessoa com deficiência, visando à sua inclusão social e cidadania" (art. $1^{\circ}$, do Estatuto) ${ }^{14}$.

Sempre atenta às inúmeras demandas sociais, recentemente, dada à relevância, a Organização das Nações Unidas, no intuito de "reunir os países e a população global e decidir sobre novos caminhos, melhorando a vida das pessoas em todos os lugares", apresentou o que denominou de "17 objetivos para transformar nosso mundo", com "Objetivos de Desenvolvimento Sustentável (ODS)" traçados, baseados em oito “Objetivos de Desenvolvimento do Milênio (ODM)". A acessibilidade em cidades históricas se enquadra no item 11 - Cidades e Comunidades Sustentáveis, cujo objetivo é "tornar as cidades e os assentamentos humanos inclusivos, seguros, resilientes e sustentáveis". Consta no instrumento que:

[...] 11.3 Até 2030, aumentar a urbanização inclusiva e sustentável, e as capacidades para o planejamento e gestão de assentamentos humanos participativos, integrados e sustentáveis, em todos os países

\footnotetext{
12 BRASIL. Decreto Legislativo $n^{\circ}$. 186, de 2008. Aprova o texto da Convenção sobre os Direitos das Pessoas com Deficiência e de seu Protocolo Facultativo, assinados em Nova lorque, em 30 de março de 2007. Disponível em: http://www.planalto.gov.br/ccivil_03/CONGRESSO/DLG/DLG-186-2008.htm. Acesso em: 23 abr. 2020.

13 CENSO DEMOGRÁFICO 2010 (2012) Características gerais da população, religião e pessoas com deficiência. Rio de Janeiro, RJ. IBGE. Disponível em: https://biblioteca.ibge.gov.br/visualizacao/periodicos/94/cd_2010_religiao_deficiencia.pdf. Acesso em: 23 abr. 2020.

14 BRASIL. Lei $n^{\circ} 13.146$, de 06 de julho de 2015. Institui a Lei Brasileira de Inclusão da Pessoa com Deficiência (Estatuto da Pessoa com Deficiência). In: Diário Oficial da União: seção 1, Brasília, DF, ano CLII $\mathrm{n}^{\circ}$ 127, p. 2-11, 07 jul. 2015. Disponível em: http://www.planalto.gov.br/ccivil_03/_ato20152018/2015/lei/l13146.htm. Acesso em: 23 abr. 2020.
} 
11.4 Fortalecer esforços para proteger e salvaguardar o patrimônio cultural e natural do mundo [...]

11.7 Até 2030, proporcionar o acesso universal a espaços públicos seguros, inclusivos, acessíveis e verdes, particularmente para as mulheres e crianças, pessoas idosas e pessoas com deficiência [...]. ${ }^{15}$

Por óbvio, há outras tantas violações de direitos em face da pessoa com deficiência. Muitas delas passíveis até mesmo de sanção penal. O processo de conscientização social tem sido constante, ainda que lento, visando uma vida digna, em uma sociedade mais justa e inclusiva, em todos os aspectos.

\section{DO DIREITO À ACESSIBILIDADE NA PERSPECTIVA DA PESSOA COM DEFICIÊNCIA}

Muito embora o tema direito à acessibilidade esteja associado ao tema pessoa com deficiência - e o crescente número dessa parcela da população justifica a preocupação -, as projeções atestadas em pesquisas revelam o envelhecimento da população, reforçando, então, que a aplicação recursos públicos aqui reverberará em autonomia, vida independente e com qualidade para muitos.

Historicamente, a partir da década de 1940, o termo acessibilidade estava atrelado às questões voltadas para a pessoa com deficiência. No entanto, só na década de 1980 é impulsionado pela pressão do “Ano Internacional das Pessoas Deficientes" (1981), com campanhas mundiais para integrar essas pessoas aos ambientes.

Em 1985, surge o termo “desenho universal”, criado pelo arquiteto Ronald Lawrence Mace (1941-1998), segundo o qual os ambientes, os meios de transportes e os mobiliários devem ser projetados para todos e não apenas para pessoas com deficiência.

Primariamente, a acessibilidade é tratada nas Leis 10.048/2000, 10.098/2000, regulamentadas pelo Decreto 5.296/2004.

Dentre tantas áreas abordadas pela LBI e acreditando que os ganhos nela auferidos alcancem a todos - e não somente à pessoa com deficiência -, ou, ao menos, aos que almejam uma sociedade com mais justiça social e inclusão, a população brasileira é presenteada com uma

15 ONU. Organização das Nações Unidas. 17 objetivos para transformar o mundo. 2015. Disponível em: https://nacoesunidas.org/pos2015/ods11/. Acesso em: 23 abr. 2020. 
maior amplitude do conceito de acessibilidade. Ampliando seu enfoque, a LBI alterou a Lei $10.098 / 2000$.

A amplitude do conceito de acessibilidade resultará na autonomia ou na falta dela para uma gama de pessoas muito maior que a original.

O senso comum leva tantos a pensarem, ao se falar em acessibilidade, no limitado uso de rampas por usuários de cadeiras de rodas. Todavia, para o pleno exercício dos direitos, ou seja, com autonomia e independência, é legítimo o acesso aos mesmos serviços e bens disponíveis a todos os cidadãos. As leis e normas vigentes ditam e exigem a observância de práticas e locais acessíveis que vão além do exemplo dado.

Nesse sentido, destaca Bueno et al. que "o termo acessibilidade não está relacionado tão somente com o direito de ir e vir”, de um lugar para outro na cidade e nas edificações, até mesmo em sua moradia, "sem que haja qualquer tipo de barreira que impeça ou dificulte a locomoção". O termo deve ter uma compreensão e visão mais ampla, envolvendo "questões relacionadas à dignidade, à independência, à autonomia e ao desenvolvimento do indivíduo, que independentemente de suas limitações é parte fundamental na construção de uma sociedade"16 livre. Como escreve Pedrosa:

A acessibilidade ao meio físico é uma condição para possibilitar o direito de ir e vir, gerando independência das pessoas com deficiência e re/inserção delas à cidade. Dar acesso aos bens patrimoniais é democratizá-los: a acessibilidade permite compartilhar valores culturais. ${ }^{17}$

A colocação vem ao encontro de conceitos trazidos pela Lei 13.146/2015. A princípio, o próprio conceito de pessoa com deficiência, o qual, como já explorado, foi visto de maneira mais ampla após o advento da Lei Brasileira de Inclusão da Pessoa com Deficiência e o Estado deve se organizar para acompanhar os reflexos dessa determinação legal. Acatou o legislador que:

16 BUENO, Léia Soares; GUEDES, Leonardo Guerra de Rezende; MENDES, Gilberto Cândido Rodrigues. Acessibilidade nos espaços públicos: estudo de caso das unidades judiciárias do Estado de Goiás. Revista Baru, Goiânia, GO, v. 4, n. 2, p. 194-205, jul./dez. 2018. Disponível em: http://seer.pucgoias.edu.br/index.php/baru/article/view/6694/3893. Acesso em: 01 abr. 2021.

17 PEDROSA, Marcelo de Carvalho. Compatibilização entre Acessibilidade ao Meio Físico e Conservação do Patrimônio Cultural: o caso do Largo do Carmo, no bairro de Santo Antônio, Recife-Pe. Dissertação (Mestrado) - Universidade Federal de Pernambuco, Centro de Artes e Comunicação. Desenvolvimento Urbano, 2016. https://attena.ufpe.br/bitstream/123456789/17275/1/Disserta\%c3\%a7\%c3\%a3o_Pedrosa_FINAL.pdf. Acesso em: 01 abr. 2021. 
Art. $2^{\circ}$. Considera-se pessoa com deficiência aquela que tem impedimento de longo prazo de natureza física, mental, intelectual ou sensorial, o qual, em interação com uma ou mais barreiras, pode obstruir sua participação plena e efetiva na sociedade em igualdade de condições com as demais pessoas. ${ }^{18}$

Segundo Pimentel e Pimentel, em estudo que objetivou "analisar como a acessibilidade da pessoa com deficiência é assegurada no ordenamento jurídico brasileiro infraconstitucional como um direito fundamental", conclui-se que, "apesar de não estar explicitamente elencada na Carta Magna, a acessibilidade é um direito fundamental, pois garante a dignidade da pessoa com deficiência"19

Ainda no estudo supracitado, as autoras, tratando da historicidade e dos avanços legislativos no âmbito federal, no tocante à acessibilidade, atestam que a Lei 4.169/62 inaugura o tema ao afirmar que "oficializa as convenções do Sistema Braille para uso na escrita e leitura dos cegos e do Código de Contrações e Abreviaturas Braille, um grande passo para a diminuição da barreira comunicacional das pessoas cegas". ${ }^{20}$

Do momento descrito acima até os dias atuais, há algumas conquistas para celebrar. A evolução pode ser constatada na Convenção Internacional sobre os Direitos da Pessoa com Deficiência, que prevê em seu artigo 9, além de outras medidas, que:

A fim de possibilitar às pessoas com deficiência viver de forma independente e participar plenamente de todos os aspectos da vida, os Estados Partes tomarão as medidas apropriadas para assegurar às pessoas com deficiência o acesso, em igualdade de oportunidades com as demais pessoas, ao meio físico, ao transporte, à informação e comunicação, inclusive aos sistemas e tecnologias da informação e comunicação, bem como a outros serviços e instalações abertos ao público ou de uso público, tanto na zona urbana como na rural. $(. . .)^{21}$

\footnotetext{
18 BRASIL. Lei $\mathrm{n}^{\circ} 13.146$, de 06 de julho de 2015. Institui a Lei Brasileira de Inclusão da Pessoa com Deficiência (Estatuto da Pessoa com Deficiência). In: Diário Oficial da União: seção 1, Brasília, DF, ano CLII $n^{\circ}$ 127, p. 2-11, 07 jul. 2015. Disponível em: http://www.planalto.gov.br/ccivil_03/_ato20152018/2015/lei/l13146.htm. Acesso em: 01 abr. 2021.

19 PIMENTEL, Susana Couto; PIMENTEL, Mariana Couto. Acessibilidade como um direito fundamental: uma análise à luz das leis federais brasileiras. Revista Eletrônica do Curso de Direito da UFSM, Santa Maria, RS, v. 13, n. 1, p. 75-102, abr. 2018. ISSN 1981-3694. DOI: http://dx.doi.org/10.5902/1981369427961. Disponível em: https://periodicos.ufsm.br/revistadireito/article/view/27961. Acesso em: 23 abr. 2020.

20 PIMENTEL, Susana Couto; PIMENTEL, Mariana Couto. Acessibilidade como um direito fundamental: uma análise à luz das leis federais brasileiras. Revista Eletrônica do Curso de Direito da UFSM, Santa Maria, RS, v. 13, n. 1, p. 75-102, abr. 2018. ISSN 1981-3694. DOI: http://dx.doi.org/10.5902/1981369427961. Disponível em: https://periodicos.ufsm.br/revistadireito/article/view/27961. Acesso em: 23 abr. 2020.

21 BRASIL. Decreto Legislativo $n^{\circ}$. 186, de 2008. Aprova o texto da Convenção sobre os Direitos das Pessoas com Deficiência e de seu Protocolo Facultativo, assinados em Nova lorque, em 30 de março de 2007. Disponível em: http://www.planalto.gov.br/ccivil_03/CONGRESSO/DLG/DLG-186-2008.htm. Acesso em: 23 abr. 2020.
} 
Propiciar a acessibilidade em todas as esferas da sociedade, ainda que árduo, transcende às exigências legais. Como o óbvio muitas vezes também precisa ser dito, as legislações que contemplam definições, parâmetros, infrações em caso de descumprimento e demais determinações são aliadas nesse processo de evolução social.

Por acessibilidade, à luz da Lei Brasileira de Inclusão da Pessoa com Deficiência, artigo $3^{\circ}$. , I, entende-se:

I - acessibilidade: possibilidade e condição de alcance para utilização, com segurança e autonomia, de espaços, mobiliários, equipamentos urbanos, edificações, transportes, informação e comunicação, inclusive seus sistemas e tecnologias, bem como de outros serviços e instalações abertos ao público, de uso público ou privados de uso coletivo, tanto na zona urbana como na rural, por pessoa com deficiência ou com mobilidade reduzida; 22

Quanto às barreiras, as quais devem ser analisadas conjuntamente, cita o mesmo dispositivo legal:

IV - barreiras: qualquer entrave, obstáculo, atitude ou comportamento que limite ou impeça a participação social da pessoa, bem como o gozo, a fruição e o exercício de seus direitos à acessibilidade, à liberdade de movimento e de expressão, à comunicação, ao acesso à informação, à compreensão, à circulação com segurança, entre outros, classificadas em:

a) barreiras urbanísticas: as existentes nas vias e nos espaços públicos e privados abertos ao público ou de uso coletivo;

b) barreiras arquitetônicas: as existentes nos edifícios públicos e privados;

c) barreiras nos transportes: as existentes nos sistemas e meios de transportes;

d) barreiras nas comunicações e na informação: qualquer entrave, obstáculo, atitude ou comportamento que dificulte ou impossibilite a expressão ou o recebimento de mensagens e de informações por intermédio de sistemas de comunicação e de tecnologia da informação;

e) barreiras atitudinais: atitudes ou comportamentos que impeçam ou prejudiquem a participação social da pessoa com deficiência em igualdade de condições e oportunidades com as demais pessoas;

f) barreiras tecnológicas: as que dificultam ou impedem o acesso da pessoa com deficiência às tecnologias; ${ }^{23}$

Zelando pelo aspecto conceitual, a LBI revela a mobilidade reduzida como a que tenha, por qualquer motivo, "dificuldade de movimentação, permanente ou temporária, gerando

\footnotetext{
22 BRASIL. Lei $\mathrm{n}^{\circ}$ 13.146, de 06 de julho de 2015. Institui a Lei Brasileira de Inclusão da Pessoa com Deficiência (Estatuto da Pessoa com Deficiência). In: Diário Oficial da União: seção 1, Brasília, DF, ano CLII $\mathrm{n}^{\circ}$ 127, p. 2-11, 07 jul. 2015. Disponível em: http://www.planalto.gov.br/ccivil_03/_ato20152018/2015/lei/l13146.htm. Acesso em: 23 abr. 2020.

${ }^{23}$ BRASIL. Lei $\mathrm{n}^{\circ} 13.146$, de 06 de julho de 2015. Institui a Lei Brasileira de Inclusão da Pessoa com Deficiência (Estatuto da Pessoa com Deficiência). In: Diário Oficial da União: seção 1, Brasília, DF, ano CLII $\mathrm{n}^{\circ}$ 127, p. 2-11, 07 jul. 2015. Disponível em: http://www.planalto.gov.br/ccivil_03/_ato20152018/2015/lei/l13146.htm. Acesso em: 01 abr. 2021.
} 
redução efetiva da mobilidade, da flexibilidade, da coordenação motora ou da percepção, incluindo idoso, gestante, lactante, pessoa com criança de colo e obeso". ${ }^{24}$

Agrupando e contextualizando, na mesma lei, o legislador reforça o tema, em seu artigo 53, ao prever: "a acessibilidade é direito que garante à pessoa com deficiência ou com mobilidade reduzida viver de forma independente e exercer seus direitos de cidadania e de participação social". ${ }^{25}$

Mesmo nas mais privilegiadas sociedades do mundo, inúmeros são os que não se encaixam e são excluídos por não espelharem os padrões exigidos na inclusão. Inadmitidos a gozar de uma vida digna.

Garantir a acessibilidade no seu mais amplo sentido é possibilitar uma condição de igualdade a todos os cidadãos.

Assim, para normatizar e alinhar, os parâmetros necessários no atendimento da acessibilidade a edificações, mobiliários, espaços e equipamentos urbanos são definidos pela Associação Brasileira de Normas Técnicas (ABNT) e estão na Norma Brasileira (NBR) 9050:2020, acrescida da Emenda 1, de 03.08.2020, que trata de Acessibilidade a edificações, mobiliário, espaços e equipamentos urbanos. Para a sua obrigatoriedade, houve a publicação do Decreto $\mathrm{n}^{\circ}$. 9.296/2018, regulamentando o artigo 45, da Lei 13.146/2015. “A ABNT NBR 9050 foi elaborada no Comitê Brasileiro de Acessibilidade (ABNT/CB-040), pela Comissão de Estudo de Acessibilidade em Edificações (CE-040:000.001). O Projeto circulou em Consulta Nacional de acordo com o Edital n ${ }^{\circ}$ 08, de 20.08.2012 a 18.10.2012"26, conforme descrito no documento.

Para o atendimento da acessibilidade, tal norma deve ser respeitada. Nesse diapasão, descreve acessibilidade como a

possibilidade e condição de alcance, percepção e entendimento para utilização, com segurança e autonomia, de espaços, mobiliários, equipamentos urbanos, edificações, transportes, informação e comunicação, inclusive seus sistemas e tecnologias, bem como outros serviços e instalações abertos ao público, de uso

${ }^{24}$ BRASIL. Lei $\mathrm{n}^{\circ} 13.146$, de 06 de julho de 2015. Institui a Lei Brasileira de Inclusão da Pessoa com Deficiência (Estatuto da Pessoa com Deficiência). In: Diário Oficial da União: seção 1, Brasília, DF, ano CLII $\mathrm{n}^{\circ}$ 127, p. 2-11, 07 jul. 2015. Disponível em: http://www.planalto.gov.br/ccivil_03/_ato20152018/2015/lei/l13146.htm. Acesso em: 01 abr. 2021

${ }^{25}$ BRASIL. Lei $\mathrm{n}^{\circ} 13.146$, de 06 de julho de 2015. Institui a Lei Brasileira de Inclusão da Pessoa com Deficiência (Estatuto da Pessoa com Deficiência). In: Diário Oficial da União: seção 1, Brasília, DF, ano CLII $\mathrm{n}^{\circ}$ 127, p. 2-11, 07 jul. 2015. Disponível em: http://www.planalto.gov.br/ccivil_03/_ato20152018/2015/lei/l13146.htm. Acesso em: 01 abr. 2021

26 ABNT. Associação Brasileira de Normas Técnicas. NBR 9050:2020. Quarta edição. 03.08.2020. 147 páginas. ISBN 978-65-5659-371-5. 
público ou privado de uso coletivo, tanto na zona urbana como na rural, por pessoa com deficiência ou mobilidade reduzida. ${ }^{27}$

$\mathrm{E}$, no que diz respeito a bens tombados, ela assim entende:

\subsection{Bens tombados}

10.2.1 Todos os projetos de adaptação para acessibilidade de bens tombados devem obedecer às condições descritas nesta Norma, compatibilizando soluções com os critérios estabelecidos por órgãos legisladores, e sempre garantindo os conceitos de acessibilidade.

10.2.2 No caso de sítios, áreas ou elementos considerados inacessíveis ou com visitação restrita, deve-se garantir o acesso por meio de informação visual, auditiva ou tátil das áreas ou dos elementos cuja adaptação seja impraticável, com divulgação das condições de acessibilidade do bem patrimonial informadas com antecedência ao visitante e vinculadas a todo material publicitário. ${ }^{28}$

No estudo em questão, outra definição salutar, trazida pela NBR 9050:2020, para o entendimento de considerações feitas no próximo capítulo, é sobre as rotas acessíveis. Diz a norma:

6.1.1.2 A rota acessível é um trajeto contínuo, desobstruído e sinalizado, que conecta os ambientes externos e internos de espaços e edificações, e que pode ser utilizada de forma autônoma e segura por todas as pessoas. A rota acessível externa incorpora estacionamentos, calçadas, faixas de travessias de pedestres (elevadas ou não), rampas, escadas, passarelas e outros elementos da circulação. A rota acessível interna incorpora corredores, pisos, rampas, escadas, elevadores e outros elementos da circulação. ${ }^{29}$

Antes da norma em questão, não havia equidade dos conceitos ou dos critérios adotados. $\mathrm{O}$ que resultava em insegurança tanto para quem buscava atender à acessibilidade nas edificações, mobiliários, espaços e equipamentos urbanos, como para quem necessitava usufruir dessa acessibilidade, em razão de sua condição. Com a norma, os critérios e os parâmetros técnicos foram estabelecidos.

27 ABNT. Associação Brasileira de Normas Técnicas. NBR 9050:2020. Quarta edição. 03.08.2020. 147 páginas. ISBN 978-65-5659-371-5.

28 ABNT. Associação Brasileira de Normas Técnicas. NBR 9050:2020. Quarta edição. 03.08.2020. 147 páginas. ISBN 978-65-5659-371-5.

29 ABNT. Associação Brasileira de Normas Técnicas. NBR 9050:2020. Quarta edição. 03.08.2020. 147 páginas. ISBN 978-65-5659-371-5. 


\section{DA PRESERVAÇÃO DO PATRIMÔNIO CULTURAL BRASILEIRO}

$\mathrm{Na}$ busca por igualdades de condições, esbarra-se em outras searas. Dentre tantas, temse o dever de preservação do Patrimônio Cultural Brasileiro, responsabilidade atribuída ao Instituto do Patrimônio Histórico e Artístico Nacional (IPHAN), autarquia federal vinculada ao Ministério do Turismo. Todavia, a preservação nem sempre favorece a acessibilidade.

O Instituto foi criado em 13 de janeiro de 1937, por meio da Lei $n^{\circ} 378$, assinada pelo presidente Getúlio Vargas, no seu artigo 46: “Fica criado o Serviço do Patrimônio Histórico e Artístico Nacional, com a finalidade de promover, em todo o País e de modo permanente, o tombamento, a conservação, o enriquecimento e o conhecimento do patrimônio histórico e artístico nacional."30

Entende-se por patrimônio cultural brasileiro, para a Constituição Federal de 1988:

Art. 216. Constituem patrimônio cultural brasileiro os bens de natureza material e imaterial, tomados individualmente ou em conjunto, portadores de referência à identidade, à ação, à memória dos diferentes grupos formadores da sociedade brasileira, nos quais se incluem:

I - as formas de expressão;

II - os modos de criar, fazer e viver;

III - as criações científicas, artísticas e tecnológicas;

IV - as obras, objetos, documentos, edificações e demais espaços destinados às manifestações artístico-culturais;

V - os conjuntos urbanos e sítios de valor histórico, paisagístico, artístico, arqueológico, paleontológico, ecológico e científico. ${ }^{31}$

Se, por um lado, tem-se a rigidez da legislação vigente em preservar o patrimônio cultural brasileiro, dever do Estado, com a colaboração da comunidade (art. 216, § $1^{\circ}, \mathrm{CF} / 88$ ), por outro, existe a necessidade e, sobretudo, o direito de garantir a acessibilidade das pessoas com deficiência em todos os lugares, até mesmo, nas cidades históricas.

Assim, o ordenamento jurídico brasileiro, no que tange à preservação e à conservação de cidades, centros históricos, casas, dentre outros locais delimitados como patrimônios históricos e culturais, é considerado rígido, sendo previstas penalidades em caso de infrações. Não obstante, essa discussão perpassa por perspectivas diversas (princípio da dignidade humana, direito à acessibilidade, direito de ir e vir, legislações aplicadas) que também devem ser

${ }^{30}$ BRASIL. Lei n 378, de 13 de janeiro de 1937. Dá nova organização ao Ministério da Educação e Saúde Pública. In: Diário Oficial da União, p. 1210, 15 jan. 1937. Disponível em: https://www.planalto.gov.br/ccivil_03/leis/1930-1949/l0378.htm. Acesso em: 23 abr. 2020.

31 BRASIL. Constituição Federal. Brasília: Senado Federal, 1988. Disponível em: http://www.planalto.gov.br/ccivil_03/constituicao/constituicao.htm. Acesso em: 23 abr. 2020. 
atendidas. Imperioso se faz atentar se as adaptações indispensáveis às políticas de acessibilidade estão sendo devidamente respeitadas nos edifícios e espaços públicos, considerados patrimônio histórico, oportunizando a todos.

Para tanto, a Instrução Normativa $\mathrm{n}^{\circ}$ 1, de 2003, emitida pelo IPHAN, que dispõe sobre a acessibilidade aos bens culturais imóveis acautelados em nível federal, pode ser, afinal, 0 amparo legal fundamental, capaz de dirimir sobre os desafios no atendimento às legislações referentes à preservação de patrimônio histórico e à acessibilidade. 0 que não ocorreu.

Vale citar fragmentos da instrução que, em que pese seu conteúdo verse sobre o acesso aos bens culturais imóveis e tenha como fim "equiparar as oportunidades de fruição destes bens pelo conjunto da sociedade, em especial pelas pessoas portadoras de deficiência ou com mobilidade reduzida" 32 , apresenta lacunas para os que entenderem aplicá-la de forma a prestigiar a preservação do patrimônio em detrimento da acessibilidade. Seguem os destaques:

\section{(...)}

1.1 - Tendo como referências básicas a LF 10.098/2000, a NBR9050 da ABNT e esta Instrução Normativa, as soluções adotadas para a eliminação, redução ou superação de barreiras na promoção da acessibilidade aos bens culturais imóveis devem compatibilizar-se com a sua preservação e, em cada caso específico, assegurar condições de acesso, de trânsito, de orientação e de comunicação, facilitando a utilização desses bens e a compreensão de seus acervos para todo o público, observadas as seguintes premissas:

a) - As intervenções poderão ser promovidas através de modificações espaciais e estruturais, pela incorporação de dispositivos, sistemas e redes de informática; bem como pela utilização de ajudas técnicas e sinalizações específicas de forma a assegurar a acessibilidade plena, sempre que possível, devendo ser legíveis como adições do tempo presente, em harmonia com o conjunto.

$(\ldots)$

c) - O limite para a adoção de soluções em acessibilidade decorrerá da avaliação sobre a possibilidade de comprometimento do valor testemunhal e da integridade estrutural resultantes. ${ }^{33}$ (grifos nossos)

32 IPHAN. Instituto do Patrimônio Histórico e Artístico Nacional. Instrução Normativa $\mathrm{n}^{\circ} \mathbf{1}$, de 25 de novembro de 2003. Acessibilidade aos bens culturais imóveis acautelados em nível federal, e outras categorias, conforme especifica. $\quad$ Disponível em: http://portal.iphan.gov.br/uploads/legislacao/Instrucao_Normativa_n_1_de_25_de_novembro_de_2003.p df. Acesso em: 02 abr. 2021.

33 IPHAN. Instituto do Patrimônio Histórico e Artístico Nacional. Instrução Normativa $n^{\circ} 1$, de 25 de novembro de 2003. Acessibilidade aos bens culturais imóveis acautelados em nível federal, e outras categorias, conforme especifica. Disponível em: http://portal.iphan.gov.br/uploads/legislacao/Instrucao_Normativa_n_1_de_25_de_novembro_de_2003.p df. Acesso em: 02 abr. 2021. 
Coloquial e juridicamente, é sabido que os termos grifados acima possuem conceitos abertos, lacunas que permitem margear interpretações subjetivas e apresentam-se como possíveis escusas, desobrigando a observação daquele que projeta e executa, em caso de descumprimento, estando revestido com a permissão legal.

Garantir aos sítios de preservação histórica o pleno acesso é a maneira de fazê-los cumprir o seu papel de referência à memória e identidade de um povo.

Ferreira apud Ubierna delimita o binômio patrimônio e acessibilidade como “dois mundos que jamais se encontraram - ou se o fizeram - foi mais em razão do acaso que de um propósito funcional definido." Adiante, abranda a análise, aclarando:

O campo da acessibilidade, se realmente pretende trabalhar com rigor no território do patrimônio, e fazê-lo com precisão, comedimento, eficácia e imaginação, precisa dispor de um conhecimento o mais completo possível da temática do patrimônio, em suas muitas faces, tanto da história que se molda nestes bens como em suas diferentes tipologias, características construtivas, materiais, funcionalidade, uso e composição estética e arquitetônica. ${ }^{34}$

Quiçá a solução esteja em identificar o equilíbrio em não descaracterizar o patrimônio e prover a acessibilidade. Situações não exatamente antagônicas. Assim, entendeu Ribeiro:

Para a proposição de soluções de acessibilidade aos bens culturais, devem ser cumpridos dois requisitos: não produzir resultados incoerentes com o conjunto $\mathrm{e}$ dar respostas às necessidades de qualquer visitante ou usuário. A reversibilidade das intervenções é importante, uma vez que os avanços tecnológicos poderão possibilitar a troca dos materiais por outros mais adequados ao longo do tempo.

Em resumo, a supressão de barreiras nos acessos aos bens culturais deve ser executada de modo a:

a) resguardar a integridade estrutural dos imóveis;

b) evitar a descaracterização do ambiente natural e construído;

c) propiciar maior comunicação entre o usuário e o bem cultural;

d) promover a livre circulação por todos os espaços;

e) possibilitar a utilização de comodidades tais como espaços para repouso de visita e sanitários além de equipamentos e mobiliário urbanos. ${ }^{35}$

Mais incisiva que a Instrução Normativa $n^{\circ} 1 / 2003$, do IPHAN, a Lei 10.098/2000 não flexibiliza o entendimento ao arbítrio de quem projeta e executa. Cabe esclarecer que, na

34 FERREIRA, Oscar Luís. Orientador Prof. Dr. Andrey Rosenthal Schlee. Patrimônio Cultural e Acessibilidade. As intervenções do programa Monumenta, de 2000 a 2005 . Programa de Pesquisa e Pósgraduação. Faculdade de Arquitetura e Urbanismo. Universidade de Brasília, p. 321. 2011. Disponível em: https://repositorio.unb.br/handle/10482/9381. Acesso em: 02 de abr. 2021.

35 IPHAN. Mobilidade e acessibilidade urbana em centros históricos / organização de Sandra Bernardes Ribeiro. - Brasília : Iphan, 2014. 120 p. (Cadernos Técnicos; 9). Disponível em: http://portal.iphan.gov.br/uploads/publicacao/CadTec9_CadernoAcessibilidade_m.pdf. Acesso em: 02 abr. 2021. 
hierarquia das normas, as leis federais, as quais possuem suas matérias discutidas e aprovadas por deputados ou senadores e, posteriormente, sancionadas pelo chefe do Poder Executivo, o Presidente da República, estão acima das resoluções e instruções normativas. Diz a lei:

Art. 11. A construção, ampliação ou reforma de edifícios públicos ou privados destinados ao uso coletivo deverão ser executadas de modo que sejam ou se tornem acessíveis às pessoas portadoras de deficiência ou com mobilidade reduzida.

Parágrafo único. Para os fins do disposto neste artigo, na construção, ampliação ou reforma de edifícios públicos ou privados destinados ao uso coletivo deverão ser observados, pelo menos, os seguintes requisitos de acessibilidade:

I - nas áreas externas ou internas da edificação, destinadas a garagem e a estacionamento de uso público, deverão ser reservadas vagas próximas dos acessos de circulação de pedestres, devidamente sinalizadas, para veículos que transportem pessoas portadoras de deficiência com dificuldade de locomoção permanente;

II - pelo menos um dos acessos ao interior da edificação deverá estar livre de barreiras arquitetônicas e de obstáculos que impeçam ou dificultem a acessibilidade de pessoa portadora de deficiência ou com mobilidade reduzida;

III - pelo menos um dos itinerários que comuniquem horizontal e verticalmente todas as dependências e serviços do edifício, entre si e com o exterior, deverá cumprir os requisitos de acessibilidade de que trata esta Lei; e

IV - os edifícios deverão dispor, pelo menos, de um banheiro acessível, distribuindo-se seus equipamentos e acessórios de maneira que possam ser utilizados por pessoa portadora de deficiência ou com mobilidade reduzida.

Art. 12. Os locais de espetáculos, conferências, aulas e outros de natureza similar deverão dispor de espaços reservados para pessoas que utilizam cadeira de rodas, e de lugares específicos para pessoas com deficiência auditiva e visual, inclusive acompanhante, de acordo com a ABNT, de modo a facilitar-lhes as condições de acesso, circulação e comunicação. ${ }^{36}$

Os instrumentos legais e os compromissos internacionais firmados, também, foram grandes avanços e estimuladores para a luta pelos direitos da pessoa com deficiência. Prova disso foi a publicação da Lei Brasileira de Inclusão da Pessoa com Deficiência - resultado, sem sombra de dúvida, de anos de debate, mas, principalmente, da assinatura da Convenção Internacional sobre os Direitos da Pessoa com Deficiência. Porém, os enfrentamentos às barreiras, contra uma participação de forma justa e igualitária, persistem.

\footnotetext{
${ }^{36}$ BRASIL. Lei $\mathrm{n}^{\circ} 10.098$, de 19 de dezembro de 2000. Estabelece normas gerais e critérios básicos para a promoção da acessibilidade das pessoas portadoras de deficiência ou com mobilidade reduzida, e dá outras providências. Disponível em: http://www.planalto.gov.br/ccivil_03/leis//10098.htm. Acesso em: 05 abr. 2021.
} 


\section{DAS CIDADES HISTÓRICAS: DA PROTEÇÃO À ACESSIBILIDADE}

Muito embora o IPHAN tenha sido instituído no ano de 1937, apenas na década de 70 programas direcionados à conservação de conjuntos urbanos ganham "força renovada" e não são mais tratados sob a perspectiva da cidade como "obra de arte". Para tanto, em 1975 foi criado o Programa de Cidades Históricas (PCH). A atuação do IPHAN não é marcante nesse período e muitos municípios desenvolveram projetos próprios. Quase 30 (trinta) anos depois, em dezembro de 1999, na cidade de Petrópolis (RJ), é lançado o Programa MONUMENTA, mediante acordo firmado entre o Ministério da Cultura e a UNESCO.

Os autores Castriota et al. esclarecem que:

Em outubro de 2009, o presidente da República Luis Inácio Lula da Silva lançou em Ouro Preto (MG), o Programa de Aceleração do Crescimento das Cidades Históricas. A solenidade foi realizada na Praça Tiradentes, com a presença de diversos ministros, do presidente do Instituto do Patrimônio Histórico e Artístico Nacional, do governador do estado de Minas Gerais, e de diversos prefeitos e autoridades. Cerimônia solene para se lançar um programa que deverá destinar R\$ 890 milhões para a preservação do patrimônio histórico nacional, quantia inédita na área. Através dele, as cidades históricas contempladas poderão receber obras de requalificação e infraestrutura urbana e de recuperação de monumentos e imóveis públicos. Também estão previstas ações de divulgação, nacional e internacionalmente, de sítios históricos, espaços públicos, monumentos e símbolos socioculturais do país, além de cursos de especialização para guias de turismo e da criação de uma página na internet bilíngue sobre as cidades. ${ }^{37}$

Com 422 (quatrocentos e vinte e dois) empreendimentos contemplados, aprofundando sobre os benefícios do PAC - Cidades Históricas, Fridman et al. acentuam que:

A concepção do PAC - Cidades Históricas, o maior programa de investimentos que o país já teve nesse âmbito, incluiu a defesa do patrimônio cultural, da ambiência e do meio ambiente como indutores da reabilitação urbana e indicou uma nova ideia: aliar os instrumentos do planejamento urbano às ações de preservação e restauração não limitadas às intervenções físicas sobre os conjuntos históricos. Apoiando-se na definição da "área urbana de interesse patrimonial", incluindo o monumento, seu entorno e sua área de influência, o Plano de Ação tornou-se o principal instrumento da política territorial. 0 financiamento do Programa por empresas e pelo BNDES, a CEF e o BNB - todos bancos públicos - revela uma perspectiva autônoma no país. Contudo, o PAC -

37 CASTRIOTA, Leonardo Barci; ARAÚJO, Guilherme Maciel; CARDOZO, Kelly; SOUSA, Vilmar Pereira de. PAC Cidades Históricas - oportunidade para a conservação integrada? Locus: revista de história. Juiz de Fora. $\quad$ v. $16 . \quad$ n. $2 . \quad$ p. 93-117, 2010. Disponível em: https://www.academia.edu/1115182/PAC_Cidades_Hist\%C3\%B3ricas_oportunidade_para_a_conserva\%C3\% A7\%C3\%A30_integrada_PAC_historic_cities_-_an_opportunity_for_integrated_conservation_. Acesso em: 23 abr. 2020. 
Cidades Históricas também determinou que as estratégias deveriam articular-se igualmente às iniciativas de desenvolvimento do setor turístico, sobretudo aquelas vinculadas aos grandes eventos. Ainda assim, reconhecemos que reformas foram realizadas e ganharam-se espaços para a expressão e a representatividade de segmentos sociais anteriormente marginalizados. ${ }^{38}$

O PAC - Cidades Históricas - o maior programa de investimentos - teve participação ativa do IPHAN, ao contrário dos demais programas. A fim de se alcançar soluções específicas, úteis e adequadas capazes de "compatibilizar a mobilidade e a acessibilidade com a preservação de áreas de interesse cultural", reconhece o IPHAN que "Acessibilidade urbana e patrimônio cultural são temas complexos que exigem um tratamento cuidadoso, não existindo receitas prontas a serem aplicadas". Afirma ainda que não é possível desenvolver uma teoria que possa ser aplicada a todos os espaços consagrados patrimônio cultural". 39

Oportunamente, vale dizer que o Plano Diretor, aprovado por lei municipal e obrigatório nas urbes com mais de vinte mil habitantes, "é o instrumento básico da política de desenvolvimento e expansão urbana"40, conforme o artigo 40, da Lei 10.257/2001 (Estatuto da Cidade), e deve ser revisto, pelo menos, a cada 10 (dez) anos. Na citada lei, o parágrafo $3^{\circ}$, do artigo 41, aduz sobre a garantia da acessibilidade:

§ 30 As cidades de que trata o caput deste artigo devem elaborar plano de rotas acessíveis, compatível com o plano diretor no qual está inserido, que disponha sobre os passeios públicos a serem implantados ou reformados pelo poder público, com vistas a garantir acessibilidade da pessoa com deficiência ou com mobilidade reduzida a todas as rotas e vias existentes, inclusive as que concentrem os focos geradores de maior circulação de pedestres, como os órgãos públicos e os locais de prestação de serviços públicos e privados de saúde, educação, assistência social, esporte, cultura, correios e telégrafos, bancos, entre outros, sempre que possível de maneira integrada com os sistemas de transporte coletivo de passageiros. ${ }^{41}$ (grifos nossos)

\footnotetext{
${ }^{38}$ FRIDMAN, Fania; ARAUJO, Ana Paula Silva de; DAIBERT, André Barcelos Damasceno. Políticas públicas de preservação do patrimônio histórico no Brasil. Três estudos de caso (1973-2016). Rev. Bras. Estud. Urbanos Reg., São Paulo, v. 21, n. 3, p. 621-638, Dec. 2019. Disponível em: http://www.scielo.br/pdf/rbeur/v21n3/2317-1529-rbeur-21-03-621.pdf. Acesso em: 23 abr. 2020.

39 IPHAN. Mobilidade e acessibilidade urbana em centros históricos / organização de Sandra Bernardes Ribeiro. - Brasília : Iphan, 2014. 120 p. (Cadernos Técnicos; 9). Disponível em: http://portal.iphan.gov.br/uploads/publicacao/CadTec9_CadernoAcessibilidade_m.pdf. Acesso em: 23 abr. 2020.

${ }^{40}$ BRASIL. Lei $n^{\circ} 10.257$, de 10 de julho de 2001. Regulamenta os arts. 182 e 183 da Constituição Federal, estabelece diretrizes gerais da política urbana e dá outras providências. Disponível em: http://www.planalto.gov.br/ccivil_03/leis/LEIS_2001/L10257.htm. Acesso em: 05 abr. 2021.

${ }_{41}$ BRASIL. Lei $n^{\circ} 10.257$, de 10 de julho de 2001. Regulamenta os arts. 182 e 183 da Constituição Federal, estabelece diretrizes gerais da política urbana e dá outras providências. Disponível em: http://www.planalto.gov.br/ccivil_03/leis/LEIS_2001/L10257.htm. Acesso em: 05 abr. 2021.
} 
Ainda que existente um arcabouço jurídico amplo, formado por leis e normas em vigor, pode não ser suficiente para certificar que a pessoa com deficiência terá o seu direito à acessibilidade, em cidades históricas, assegurado. As barreiras atitudinais, definidas pela LBI como "atitudes ou comportamentos que impeçam ou prejudiquem a participação social da pessoa com deficiência em igualdade de condições e oportunidades com as demais pessoas" (art. $3^{\circ}$, IV, e $)^{42}$, atravessam fronteiras, e eventuais decisões políticas corroboram para o não cumprimento das normas jurídicas. Assim, contextualiza Dias:

\begin{abstract}
Entende-se que transformações no que diz respeito a forma como essas pessoas precisam ser vistas pela sociedade requer não apenas ações políticas, NBRs, mas mudanças que possam atingir a curto e a longo prazo. Acessibilizar áreas de acesso público além de direito da pessoa com deficiência, ajudaria a descontruir barreiras, a real inserção dos mesmos no mercado de trabalho ajuda-os na autoestima tanto quanto os insere novamente no padrão "produtivo" da sociedade capitalista. ${ }^{43}$
\end{abstract}

Nesse mesmo sentido, Jan Gehl afirma que, "embora os problemas das cidades não sejam todos iguais nas várias partes do mundo e em diferentes níveis de desenvolvimento econômico, são mínimas as diferenças envolvidas na inclusão da dimensão humana no planejamento urbano". E diz, ainda “a dimensão humana foi seriamente negligenciada em sua relação com o desenvolvimento urbano". ${ }^{44}$

\title{
CONCLUSÃO
}

Por meio do estudo bibliográfico e das normas analisadas, é possível concluir que há complexidade em atender as legislações referentes à preservação do patrimônio histórico e à acessibilidade da pessoa com deficiência e os possíveis entraves na efetividade e na aplicabilidade dessas normas são reais. Atender às legislações sem violação de direitos é um desafio, vez que, quando se trata de acessibilidade aos edifícios e aos espaços públicos tombados o cenário é crítico.

\footnotetext{
42 BRASIL. Lei $n^{\circ} 13.146$, de 06 de julho de 2015. Institui a Lei Brasileira de Inclusão da Pessoa com Deficiência (Estatuto da Pessoa com Deficiência). In: Diário Oficial da União: seção 1, Brasília, DF, ano CLII $n^{\circ}$ 127, p. 2-11, 07 jul. 2015. Disponível em: http://www.planalto.gov.br/ccivil_03/_ato20152018/2015/lei/l13146.htm. Acesso em: 23 abr. 2020.

43 DIAS, Renata Dutra. OLHOS QUE TOCAM O CHÃO, CORPOS NA CONTRAMÃO: PCD, acessibilidade e mobilidade no centro histórico da cidade de Goiás [manuscrito] / Renata Dias Dutra - 2018. Disponível em: https://repositorio.bc.ufg.br/tede/bitstream/tede/9259/5/Disserta\%C3\%A7\%C3\%A30\%20\%20Renata\%20Dias\%20Dutra\%20-\%202018.pdf. Acesso em: 23 abr. 2020.

${ }^{44} \mathrm{GEHL}$, Jan. Cidades para pessoas. Perspectiva. São Paulo, 2013.
} 
Inicialmente, ao descrever o histórico de invisibilidade, que culminou em uma proteção via instrumentos jurídicos internacionais e federais, é lamentável reconhecer que muitas dessas marcas de discriminação ainda sejam perceptíveis nas sociedades.

O estudo sobre a importância da acessibilidade em cidades históricas para a pessoa com deficiência se mantém em uma curva crescente. Discutido por muitos países, esse é só um dos tantos obstáculos enfrentados diariamente por essa parcela considerável da sociedade. 0 processo de conscientização social tem sido constante. Ora célere, ora moroso, mas sem retrocessos.

Tanto nas análises bibliográficas como nas legislativas é real a preocupação em: preservar o patrimônio histórico e possibilitar a acessibilidade. Aliar os dois fatores que não é uma tarefa fácil, como admitido pelo IPHAN. É certo que a inadequação do espaço físico tolhe o direito de ir e vir e de participação social, além de reforçar o entendimento da deficiência como um problema ignorado.

A ausência de barreiras atitudinais pode permitir discussões e viabilizar a busca por soluções, a fim de transformar os espaços, tornando-os acessíveis. Incluir o tema e as nuances que envolvem a acessibilidade no Plano Diretor é importante para a construção de uma cidade acessível, estabelecendo prazos, normas e obrigações para o governo local.

Com o respaldo jurídico conquistado, após anos de isolamento social e de negligência estatal, é inconcebível não fazer valer os direitos da pessoa com deficiência, em todas as áreas. 0 acesso deve ser garantido, independente do que precisar de ser feito.

A proteção ao patrimônio histórico é legítima. Conservando-o para as gerações futuras. Contudo, oportunizar o acesso da pessoa com deficiência em todos os lugares, inclusive nas cidades históricas, é imprescindível.

\section{REFERÊNCIAS}

ABNT. Associação Brasileira de Normas Técnicas. NBR 9050:2020. Quarta edição. 03.08.2020. 147 páginas. ISBN 978-65-5659-371-5.

ARANHA, Maria Salete Fábio. Integração social do deficiente: análise conceitual e metodológica. Temas psicol., Ribeirão Preto, v. 3, n. 2, p. 63-70, ago. 1995. Disponível em: http://pepsic.bvsalud.org/scielo.php?script=sci_arttext\&pid=S1413389X1995000200008\&lng=pt\&nrm=iso. Acesso em: 23 abr. 2020. 
BARROSO, Luís Roberto. A Dignidade da Pessoa Humana no Direito Constitucional Contemporâneo: Natureza Jurídica, Conteúdos Mínimos e Critérios de Aplicação. Versão provisória para debate público. Mimeografado, Dezembro de 2010. Disponível em: https://www.luisrobertobarroso.com.br/wp-content/uploads/2010/12/Dignidade_textobase_11dez2010.pdf. Acesso em: 23 abr. 2020.

BRASIL. Lei $n^{\circ}$ 378, de 13 de janeiro de 1937. Dá nova organização ao Ministério da Educação e Saúde Pública. In: Diário Oficial da União, p. 1210, 15 jan. 1937. Disponível em: https://www.planalto.gov.br/ccivil_03/leis/1930-1949//0378.htm. Acesso em: 23 abr. 2020.

BRASIL. Constituição Federal. Brasília: Senado Federal, 1988. Disponível em: http://www.planalto.gov.br/ccivil_03/constituicao/constituicao.htm. Acesso em: 23 abr. 2020.

BRASIL. Lei $\mathrm{n}^{\circ} 10.098$, de 19 de dezembro de 2000. Estabelece normas gerais e critérios básicos para a promoção da acessibilidade das pessoas portadoras de deficiência ou com mobilidade reduzida, e dá outras providências. Disponível em: http://www.planalto.gov.br/ccivil_03/leis//10098.htm. Acesso em: 05 abr. 2021.

BRASIL. Lei $n^{\circ} 10.257$, de 10 de julho de 2001. Regulamenta os arts. 182 e 183 da Constituição Federal, estabelece diretrizes gerais da política urbana e dá outras providências. Disponível em: http://www.planalto.gov.br/ccivil_03/leis/LEIS_2001/L10257.htm. Acesso em: 05 abr. 2021.

BRASIL. Decreto Legislativo $n^{\circ}$. 186, de 2008. Aprova o texto da Convenção sobre os Direitos das Pessoas com Deficiência e de seu Protocolo Facultativo, assinados em Nova lorque, em 30 de março de 2007. Disponível em: http: //www.planalto.gov.br/ccivil_03/CONGRESSO/DLG/DLG-186-2008.htm. Acesso em: 23 abr. 2020.

BRASIL. Lei $n^{\circ}$ 13.146, de 06 de julho de 2015. Institui a Lei Brasileira de Inclusão da Pessoa com Deficiência (Estatuto da Pessoa com Deficiência). In: Diário Oficial da União: seção 1, Brasília, DF, ano CLII n 127, p. 2-11, 07 jul. 2015. Disponível em:

http://www.planalto.gov.br/ccivil_03/_ato2015-2018/2015/lei//13146.htm. Acesso em: 23 abr. 2020.

BUENO, Léia Soares; GUEDES, Leonardo Guerra de Rezende; MENDES, Gilberto Cândido Rodrigues. Acessibilidade nos espaços públicos: estudo de caso das unidades judiciárias do Estado de Goiás. Revista Baru, Goiânia, GO, v. 4, n. 2, p. 194-205, jul./dez. 2018. Disponível em: http://seer.pucgoias.edu.br/index.php/baru/article/view/6694/3893. Acesso em: $01 \mathrm{abr}$. 2021.

CASTRIOTA, Leonardo Barci; ARAÚJO, Guilherme Maciel; CARDOZO, Kelly; SOUSA, Vilmar Pereira de. PAC Cidades Históricas - oportunidade para a conservação integrada? Locus: revista de história. Juiz de Fora. v. 16. n. 2. p. 93-117, 2010. Disponível em: https://www.academia.edu/1115182/PAC_Cidades_Hist\%C3\%B3ricas_oportunidade_para_a_cons erva\%C3\%A7\%C3\%A30_integrada_PAC_historic_cities__an_opportunity_for_integrated_conservation_. Acesso em: 23 abr. 2020. 
ISSN 1981-3694

(DOI): $10.5902 / 198136943962$

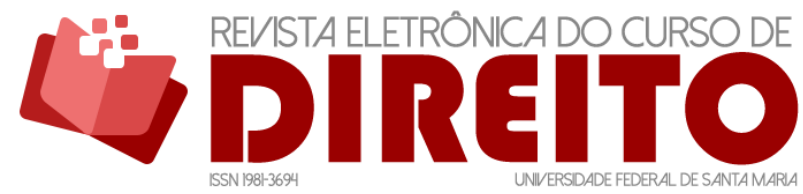

A ACESSIBILIDADE EM CIDADES HISTÓRICAS PARA AS PESSOAS COM DEFICIÊNCIAS: DESAFIOS NO CUMPRIMENTO DAS

LEGISLAÇÕES VIGENTES

LÚCIA MARIA MORAES DANIELLY APARECIDA DE SOUZA CARVALHO SANTANA

CENSO DEMOGRÁFICO 2010 (2012) Características gerais da população, religião e pessoas com deficiência. Rio de Janeiro, RJ. IBGE. Disponível em:

https://biblioteca.ibge.gov.br/visualizacao/periodicos/94/cd_2010_religiao_deficiencia.pdf.

Acesso em: 23 abr. 2020.

CORRÊA, Maria Ângela Monteiro. Educação Especial. v. 1 - $5^{a}$. reimp. Rio de Janeiro: Fundação CECIERJ, 2010. 211p. Disponível em: https://docplayer.com.br/85708679-Educacao-especialvolume-1-modulos-1-a-4-maria-angela-monteiro-correa-apoio.html. Acesso em: 23 abr. 2020.

DIAS, Renata Dutra. OLHOS QUE TOCAM O CHÃO, CORPOS NA CONTRAMÃO: PCD, acessibilidade e mobilidade no centro histórico da cidade de Goiás [manuscrito] / Renata Dias Dutra - 2018. Disponível em:

https: / / repositorio.bc.ufg.br/tede/bitstream/tede/9259/5/Disserta\%C3\%A7\%C3\%A30\%20\%20Renata\%20Dias\%20Dutra\%20-\%202018.pdf. Acesso em: 23 abr. 2020.

FERREIRA, Oscar Luís. Orientador Prof. Dr. Andrey Rosenthal Schlee. Patrimônio Cultural e Acessibilidade. As intervenções do programa Monumenta, de 2000 a 2005. Programa de Pesquisa e Pós-graduação. Faculdade de Arquitetura e Urbanismo. Universidade de Brasília. p. 321. 2011. Disponível em:

https: //repositorio.unb.br/handle/10482/9381. Acesso em: 02 de abr. 2021.

FRIAS, Lincoln; LOPES, Nairo. Considerações sobre o conceito de dignidade humana. Rev. direito GV, São Paulo, v. 11, n. 2, p. 649-670, Dec. 2015. DOI: https://doi.org/10.1590/1808-

2432201528. Disponível em: http://www.scielo.br/pdf/rdgv/v11n2/1808-2432-rdgv-11-20649.pdf. Acesso em: 23 abr. 2020.

FRIDMAN, Fania; ARAUJO, Ana Paula Silva de; DAIBERT, André Barcelos Damasceno. Políticas públicas de preservação do patrimônio histórico no Brasil. Três estudos de caso (1973-2016). Rev. Bras. Estud. Urbanos Reg., São Paulo, v. 21, n. 3, p. 621-638, Dec. 2019. Disponível em: https://www.scielo.br/pdf/rbeur/v21n3/2317-1529-rbeur-21-03-621.pdf Acesso em: 23 abr. 2020.

GEHL, Jan. Cidades para pessoas. Perspectiva. São Paulo, 2013.

IPHAN. Instituto do Patrimônio Histórico e Artístico Nacional. Disponível em: http://portal.iphan.gov.br/pagina/detalhes/872. Acesso em: 23 abr. 2020.

IPHAN. Mobilidade e acessibilidade urbana em centros históricos / organização de Sandra Bernardes Ribeiro. - Brasília : Iphan, 2014. 120 p. (Cadernos Técnicos; 9). Disponível em: http://portal.iphan.gov.br/uploads/publicacao/CadTec9_CadernoAcessibilidade_m.pdf. Acesso em: 23 abr. 2020.

IPHAN. Instituto do Patrimônio Histórico e Artístico Nacional. Instrução Normativa $\mathbf{n}^{\circ} \mathbf{1}$, de 25 de novembro de 2003. Acessibilidade aos bens culturais imóveis acautelados em nível federal, e outras categorias, conforme especifica. Disponível em: http://portal.iphan.gov.br/uploads/legislacao/Instrucao_Normativa_n_1_de_25_de_novembro_d e_2003.pdf. Acesso em: 02 abr. 2021. 
OMS. Organização Mundial de Saúde. Relatório Mundial sobre a Deficiência. Publicado pela Organização Mundial da Saúde em 2011 sob o título World Report on Disability. Disponível em: https://apps.who.int/iris/bitstream/handle/10665/44575/9788564047020_por.pdf;jsessionid=F4 BC0CC3E2F5E37A166B7F384E90D135?sequence=4. Acesso em: 23 abr. 2020.

ONU. Organização das Nações Unidas. Declaração Universal dos Direitos Humanos. Adotada e proclamada pela Resolução 217 A (III) da Assembleia Geral das Nações Unidas, em 10 de dezembro de 1948. Brasília. 1998. Disponível em: https://nacoesunidas.org/wpcontent/uploads/2018/10/DUDH.pdf. Acesso em: 23 abr. 2020.

ONU. Organização das Nações Unidas. 17 objetivos para transformar o mundo. 2015. Disponível em: https://nacoesunidas.org/pos2015/ods11/. Acesso em: 23 abr. 2020.

PEDROSA, Marcelo de Carvalho. Compatibilização entre Acessibilidade ao Meio Físico e Conservação do Patrimônio Cultural: o caso do Largo do Carmo, no bairro de Santo Antônio, Recife-Pe. Dissertação (Mestrado) - Universidade Federal de Pernambuco, Centro de Artes e Comunicação. Desenvolvimento Urbano, 2016. Disponível em:

https://attena.ufpe.br/bitstream/123456789/17275/1/Disserta\%c3\%a7\%c3\%a3o_Pedrosa_FINAL. pdf. Acesso em: 01 abr. 2021.

PIMENTEL, Susana Couto; PIMENTEL, Mariana Couto. Acessibilidade como um direito fundamental: uma análise à luz das leis federais brasileiras. Revista Eletrônica do Curso de Direito da UFSM, Santa Maria, RS, v. 13, n. 1, p. 75-102, abr. 2018. ISSN 1981-3694. DOI: http://dx.doi.org/10.5902/1981369427961. Disponível em: https://periodicos.ufsm.br/revistadireito/article/view/27961. Acesso em: 23 abr. 2020.

PIOVESAN, Flávia. A Constituição Brasileira de 1988 e os Tratados Internacionais de Proteção aos Direitos Humanos. EOS. Revista Jurídica da Faculdade de Direito. v. 2. $n^{\circ}$ I. Ano II. Curitiba: Dom Bosco, 2008. Disponível em:

http://www.observatoriodegenero.gov.br/menu/publicacoes/outros-artigos-e-publicacoes/aconstituicao-brasileira-de-1988-e-os-tratados-internacionais-de-protecao-aos-direitoshumanos/at_download/file. Acesso em: 23 abr. 2020.

Recebido em: 30.04/2020 / Aprovado em: 22.04.2021 / Publicado em: 06.05.2021

\section{COMO FAZER REFERÊNCIA AO ARTIGO (ABNT):}

MORAIS, Lúcia Maria; SANTANA, Danielly Aparecida de Souza Carvalho. A Acessibilidade em cidades históricas para as pessoas com deficiências: desafios no cumprimento das legislações vigentes. Revista Eletrônica do Curso de Direito da UFSM, Santa Maria, RS, v. 15, n. 3, e43962. 2021. ISSN 1981-3694. DOI: http://dx.doi.org/10.5902/1981369443962. Disponível em:

https://periodicos.ufsm.br/revistadireito/article/view/43962 Acesso em: dia mês. ano.

Direitos autorais 2021 Revista Eletrônica do Curso de Direito da UFSM

Editores responsáveis: Rafael Santos de Oliveira e Angela Araujo da Silveira Espindola

Esta obra está licenciada com uma Licença Creative Commons Atribuição-NãoComercial-SemDerivações 4.0 Internacional. 
ISSN 1981-3694

(DOI): $10.5902 / 198136943962$

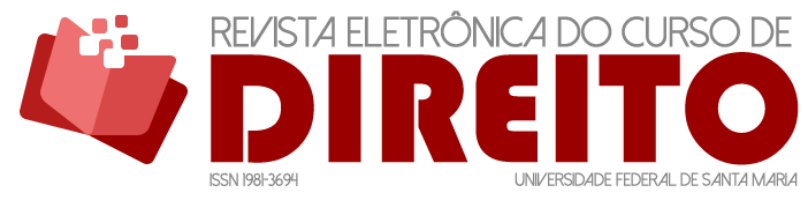

A ACESSIBILIDADE EM CIDADES HISTÓRICAS PARA AS PESSOAS COM DEFICIÊNCIAS: DESAFIOS NO CUMPRIMENTO DAS

LEGISLAÇÕES VIGENTES

LÚCIA MARIA MORAES

Danielly ApareCida de SOUZA Carvalho SANTANA

\section{SOBRE AS AUTORAS}

\section{LÚCIA MARIA MORAIS}

Doutora em Estruturas Ambientais Urbanas. Graduada em Arquitetura e Urbanismo pela Pontifícia Universidade Católica de Goiás e Doutora em Estruturas Ambientais Urbanas pela Universidade de São Paulo (FAU/USP 2003). Atualmente é professora Adjunto I e orientadora do Programa de Pós-Graduação Stricto Senso em Serviço Social e do Programa de Pós-Graduação em Desenvolvimento e Planejamento Territorial e do curso de graduação em Arquitetura e Urbanismo da Pontifícia Universidade Católica de Goiás. Foi professora convidada da Universidade Estadual de Goiás e da Uni-EVANGÉLICA de Anápolis - Goiás, e colaboradora da Plataforma Brasileira de Direitos Humanos Econômicos Sociais e Culturais e da Advisor UNhabitat.Tem experiência na área de Arquitetura e Urbanismo, com ênfase em Urbanismo, atuando principalmente nos seguintes temas: políticas públicas, projeto de arquitetura e urbanismo, segregação urbana e desenvolvimento urbano e social e assessora dos Movimentos de Moradia.

\section{DANIELLY APARECIDA DE SOUZA CARVALHO SANTANA}

Possui graduação em Direito pelo Centro Universitário de Anápolis (UniEvangélica - 2001). Advogada desde 2002. Mestre pelo Programa de Mestrado em Desenvolvimento e Planejamento Territorial pela Pontifícia Universidade Católica de Goiás. MBA em Contabilidade e Direito Tributário, com pesquisas voltadas para Carga Tributária e aplicabilidade em Políticas Públicas (2015). Professora de Pós-Graduação do CBI of Miami. Juíza do Tribunal de Ética e Disciplina da OAB/GO (triênio 2016/2018). Secretária Adjunta da Comissão dos Direitos da Pessoa com Deficiência da OAB/GO e coordenadora da Subcomissão de Educação dos Direitos da Pessoa com Deficiência (triênio 2016/2018). Membro da Comissão de Direitos Humanos, na defesa dos direitos da pessoa humana, no acesso à justiça e na busca pelos direitos sociais, e da Comissão de Direito Tributário, ambas da Ordem dos Advogados do Brasil - Seção de Goiás (triênio 2013/2015). 